\title{
Reappropriating sacramental thinking within Protestant Evangelicalism: A move towards systemic awareness
}

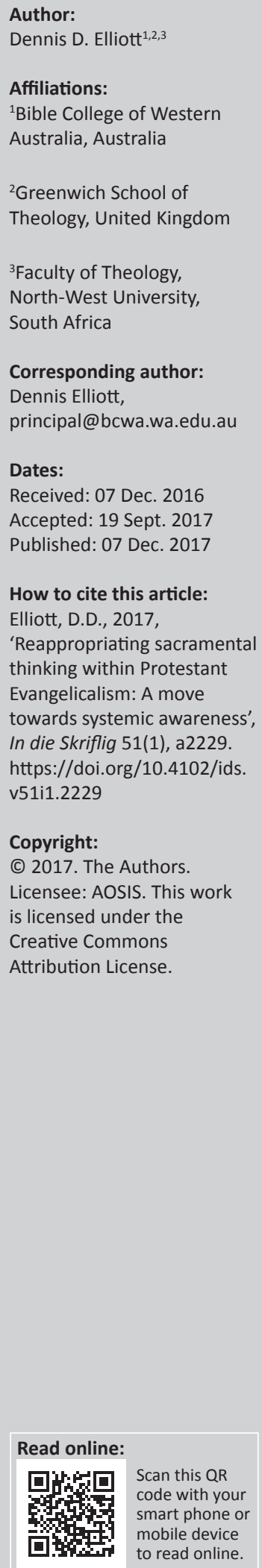

The dissertation on which this article is based, has been a polemical study aimed at exploring the sacramental theology of the late Roman Catholic theologian, Edward Schillebeeckx and thereby using it as a 'foil' against which to propose an alternative, if not renewed, ecclesiology for Protestant Evangelicalism. The study accomplished this aim within the framework of a systematic theological method with an approach that was inclusive of theological inquiry as well as sociological theory and praxis. Engaging Schillebeeckx with some significant conversation partners, both Roman Catholic and Protestants, has drawn out his hermeneutical inconsistencies. Two observations have emerged from this informed dialogue: Firstly, it established Schillebeeckx's sacramental theology as upholding the systemic awareness of Roman Catholic sacramental thought. Secondly, insofar as the Protestant tradition is concerned, it established that, in spite of the diverse sacramental views within Reformation thought and Protestant evangelicalism, in particular, the doctrine of grace is upheld as foundational for the church. With a more directed focus on the diverse views concerning the Lord's Supper, the dissertation honed in on the trajectories of Zwingli ('symbolic memorialism'), Bullinger ('symbolic parallelism') and Calvin ('symbolic instrumentalism'). Emerging from this exploration, a Zwingli-Bullinger confluence has been proposed.

\section{Sacramental thinking}

What does one make of the diverse understanding of sacramental thinking within Protestant Evangelicalism? De Chirico (2003:27), in his methodology of Protestant Evangelicalism, wisely considers the meaning, use, approaches and applications of the term Evangelical by stating that 'the attempt to define the contours of an Evangelical theology involves a deeper understanding of the Evangelical connotation of that kind of theology'. He affirms that defining the term Evangelical is not a simple task for three reasons:

Firstly, 'the increasing vagueness of the use of the word is making its semantic value less and less precise' (De Chirico 2003:28). The term does take on overtones in the different languages and nationalities, for example, in German, Evangelisch means Protestant whilst Evangelikal is applied to communities of faith outside the State church, and in the USA the term Evangelical is generally interpreted as 'a mute substantive that gains its voice only when coupled to another, and more clarifying, adjective' (De Chirico 2003:28). The multiple connotation of the term has given rise to 'hybrids' thus creating a 'semantic potpourri', because it is now 'combined with adjectives like radical, liberal, charismatic, catholic, liberationist, ecumenicalist, feminist, orthodox and others' (De Chirico 2003:28). This 'lexical supplementation' is suggestive of the 'growing taxonomy' of the term and one has to consider whether the term in the contemporary landscape and contours of Christendom is still a meaningful one (De Chirico 2003:28). Secondly, 'the intrinsic complexity of the reality' conveyed by the term does create problems of what exactly is meant by it (De Chirico 2003:29). That the term is constituted by a 'variety' or 'multiplicity of elements' does make it challenging to define (De Chirico 2003:29). Thirdly, the multifaceted approaches in attempting to understand the term by way of a 'range of interpretative keys, controlling principles and privileged perspectives' does make it increasingly difficult to arrive at a 'univocal and comprehensive understanding' (De Chirico 2003:29).

De Chirico (2003:30-40) affirms the Evangelical landscape as being constituted by:

- 'Socio-cultural categories' - Evangelicalism is beyond 'Church or Churches' and therefore must be described as a 'movement'. Institutionally, contemporary Evangelicalism comprises a 'network of Churches and para-church agencies of corporate bodies and influential personalities' as well as a 'religious culture or a cluster of subcultures' held together by a 'common nucleus' albeit with different specifications. 
- 'Historical categories' - Evangelicalism can be traced back to 'historico-theological' traditions rooted in the Reformation. These historical categories can also be traced in the XVII century orthodoxy (Protestant Scholasticism), Puritanism, continental Pietism, Revivalism, the worldwidemissionary movement, classicalPentecostalism, Dispensationalism, the early $\mathrm{XX}$ century anti-modernism Fundametalist movement, the strongly separatist subsequent Neo-Fundamentalist offshoots, the NeoEvangelical "renaissance" (as it is called by Bloesch 1973) after the Second World War and, more recently, the wide Charismatic movement.

- 'Theological categories proper' - Evangelicalism is defined by doctrinal beliefs. Wells (1987:22) describes Evangelicals as consistently 'doctrinal' people. This means that Evangelicalism is inextricably linked 'within the western tradition of Reformation-Revivalist theology'. Marsden (1984:9-10) argues that Evangelicalism is a 'conceptual unity' based upon its doctrinal emphases which are 'the final authority of Scripture'; 'the real, historical character of God's saving work recorded in Scripture'; 'eternal salvation through personal trust in Christ'; 'evangelism and missions' and a 'spiritually transformed life'. France and McGrath (1993) affirm the 'shape of Evangelicalism' through a similar approach. In his later work, McGrath (1994:53-80) also stresses the significance of 'Christian community'.

- 'Ecclesiastical categories' - The ecclesiastical element (churchly dimension) is fundamental in understanding the 'institutional configuration' of evangelical ecclesiology.

- 'Composite categories' - Bebbington (1989:2-3) notes four key distinctives that form the quadrilateral of Evangelicalism, namely, 'conversionism' (turning away from self and sin to Christ), 'biblicism' (the Bible is the ultimate authority for all matters of faith and religious experience), 'activism' (the works of social reform and charity, but, as a priority, the work of spreading the gospel) and 'crucicentrism' (Jesus' death on the cross). De Chirico (2003:39) contends that not all of these distinctives are 'theological, nor are they strictly sociocultural. Instead, they are a mixture of theological, spiritual and social Evangelical distinctives forming what might be called an Evangelical ethos'. He alludes to and prefers Tidball's 'Rubik's cube' as a more 'multifaceted approach' with more 'refined composite' categories than that of Bebbington (De Chirico 2003:39). The cube accounts for evangelical diversity with many possible combinations based on three key variables, namely Denomination, World and Spirituality (Tidball 1994:21).

Regarding the diverse theological mind-sets, methods and approaches within the diverse landscape of evangelical theology in terms of 'theological boundaries, the nature of doctrine, progress in theology, and relating to non-evangelical theologies and culture in general', Olson (1998:41) proposes a necessary distinction to be made between 'traditionalists' and 'reformists'. In this proposed distinction, traditionalists view the church as 'bounded set' whilst the reformists view it as 'centred set'; doctrine is viewed either as 'revelation' or 'interpretation' and postmodernism is viewed as an 'enemy' or a 'dialogue partner' (Olson 1998:40-50). There are other ways to describe the above-mentioned dualistic system, for example, Erickson (1997), a traditionalist, defines the reformist wing as 'left' or 'post-conservative' Evangelicalism whilst Grenz (1993; 1994), a reformist, prefers to refer to it as a 'revisionist' mind-set with regard to the 'older' or 'established' Evangelicalism (De Chirico 2003:46). Notwithstanding the 'plausibility of such clear cut analysis', De Chirico (2003) argues that the:

Evangelical theological camp is split over fundamental issues of theological method which influence the whole theological enterprise and make it possible to discern a wide spectrum of Evangelical theologies within the broad Evangelical tradition. (p. 46)

He concludes that the 'diverging sensitivities and contrasting mindsets impinges on the present state and future prospects of Evangelical theology' (De Chirico 2003:46).

In view of the varied degrees of diversity within evangelical theology, the dissertation chose to work from the angle of Noll's definition of 'Evangelical' that does incorporate all of the distinguishing characteristics mentioned above and yet does not include Protestantism in general (Noll \& McDermott 2010:19-32). For them (Noll \& McDermott 2010) 'Evangelicalism' refers to:

those Protestants who, beginning more than three hundred years ago, strongly emphasized the redeeming work of Christ, personally appropriated, and who stressed spreading the good news of that message, whether to those with only a nominal attachment to Christianity or to those who had never heard the Christian gospel. (p. 21)

Noll and McDermott (2010) endorse and list the nine 'founding commitments' of the Evangelical Alliance (formed in 1846 in England with delegates from churches across Britain, North America and many other parts of Europe) that are central to the global contemporary evangelical movement:

1. The divine inspiration, authority, and sufficiency of the Holy Scriptures

2. The right and privacy of private judgement in the interpretation of Holy Scriptures

3. The Unity of the Godhead and the Trinity of the Persons therein

4. The utter depravity of human nature in consequence of the Fall

5. The incarnation of the Son of God, His work of atonement for the sins of mankind, and His mediatorial intercession and reign

6. The justification of the sinner by faith alone

7. The work of the Holy Spirit in the conversion and sanctification of the sinner

8. The immortality of the soul, the resurrection of the body, the judgment of the world by our Lord Jesus Christ, with eternal blessedness of the righteous and the eternal punishment of the wicked 
9. The divine institution of the Christian ministry, and the obligation and perpetuity of the ordinances of Baptism and the Lord's Supper. (p. 29)

Bouyer, a convert from Protestantism to Roman Catholicism, furnishes a very vague appraisal of Protestant sacramental thinking. He (Bouyer 2004) alludes to 'uncertainty' in Protestant sacramental identification, thinking and application:

Yet if we ask why they [Protestants] perform these different rites, what use they have, the answers given seem as a general rule forced and somewhat embarrassed. As regards baptism and the Lord's Supper, they entrench themselves behind the express command of our Lord. But as they understand it the purpose of what he prescribed does not seem very clear. (p. 68)

With this in mind, it is well worth reflecting on Moltmann's perspectives as a point of departure for a reductionism in Schillebeeckx's sacramental identification and thinking (1963) as well as for a renewed hermeneutic for Protestant Evangelicalism. Moltmann advocates 'sacramental thinking' that links together the remembrance of the atoning work of Christ with the eschatological hope. He (Moltmann 1977:27-28) posits, 'the solution of the problem of faith and experience, hope and reality, the nature and form of the church, has to be looked for in pneumatology'.

Moltmann (1977) alludes to Tillich who aligns this sacramental thinking with the paradox of the Lutheran 'in spite of':

The churches are holy because of the holiness of their foundation, the New Being, which is present in them. The churches are holy, but they are so in terms of an 'in spite of or as a paradox. (p. 26)

Tillich (1948:94) cautions Protestants not to totally eliminate the 'sacramental element', otherwise it would 'lead to the dissolution of the visible church'. With the aid of 'depth psychology', he argues that Protestants need to 'recover appreciation for the sacraments, rather than only words, as mediators of Spiritual Presence in order to understand multidimensional unity' (Moore-Keish Martha in Boersma \& Levering 2015:397; Tillich 1948:94; 1963:121ff.). White (1983) posits that Protestants have come to a greater awareness of the role of the sacraments in 'faith formation'. Boersma (2011) proposes that Protestant Evangelicalism 'recover a premodern worldview in which created things have value only as they participate in heavenly realities - what he calls "a sacramental tapestry"' (Moore-Keish Martha in Boersma \& Levering 2015).

The primary tension that surrounds sacramental thinking within Protestantism is whether or not the sacraments are the means of grace and how is one to interpret the presence of Christ in the sacraments. This debate of the Reformation has since marked a separation in theological Eucharistic thought between the Lutheran tradition and the Reformed tradition. Luther, whilst opposing the Roman Catholic concept of transubstantiation, held that the body and blood of Christ were present 'in, with, and under' the bread and wine (Erickson 2001:364). This way of thinking came to be known as consubstantiation. Luther's view of the mode of Christ's presence in the Eucharist strongly emphasises the real presence of Christ rather than a mere spiritual presence (Lee 2011).

Where Luther was vague in his sacramental thinking, Calvin was precise. Calvin held that Christ is not 'physically or bodily' present in the Lord's Supper, but that his presence is 'spiritual or dynamic' (Erickson 2001:365). Mannion and Van der Borght (2011:223) argue that 'Calvin's understanding of Christ's presence in the sacrament in the Spirit is generally understood as an alternative for Roman Catholic transubstantiation and Lutheran consubstantiation'. It is certainly viable, but not adequate, because, for example, Janse, the historical theologian concludes that, in his view, one cannot speak any longer of 'The' sacramental theology of Calvin, because, in his varied Eucharistic interpretations, one finds him more Zwinglian and yet in another, more Lutheran (Mannion \& Van der Borght 2011:227). Calvin's hermeneutics on the sacraments as the means of grace is problematic and Kuyper rightfully posits that Calvin "incorrectly ascribed a 'magical power' and 'excessive stability' to the sacraments" (John Halsey Wood Jr. in Mannion \& Van der Borght 2011:171). Kuyper's spiritualised ecclesiology was exemplified by the sacraments and, in my view, he correctly argued that the sacraments 'promoted Christian unity but lacked any gracious efficacy' (John Halsey Wood Jr. in Mannion \& Van der Borght 2011:171). Conclusively, for Kuyper:

Baptism and the Supper are actions of a symbolic appointing, which in the glorious memory of our Lord advance the unity of the institute of the church, and at the same time also pricking and inspiring us, in order that we may embrace Christ with a whole heart and that we may foster the most tender love towards our brothers. (John Halsey Wood Jr. in Mannion \& Van der Borght 2011:171)

Zwingli's views on sacramental thinking and, more specifically that on the Lord's Supper, are a more viable alternative for Schillebeeckx's hermeneutics. Zwingli held that the Lord's Supper is basically a commemoration of the death of Christ on the cross and that its sacramental value 'lies in simply receiving by faith the benefits of Christ's death' (Erickson 2001:365; Hodge 1952:627-628). Zwingli argues further that the effect of the Lord's Supper is no different in nature from the preaching of the Word, because both are 'types of proclamation' which require the 'absolute essential of faith if there is to be any benefit' (Erickson 2001:365; Strong 1907:541-543). Put another way, he posited 'that it is not so much that the sacrament brings Christ to the communicant as that the believer's faith brings Christ to the sacrament' (Erickson 2001:365). Zwingli held that the bread and wine represent the body and blood of Christ (Erickson 2001:366; Strong 1907:653-654).

When Moltmann argues for 'the presence of Christ's coming in the bread and wine', he affirms Christ's sacramental presence in the Spirit as definitive and dynamic. He discusses the Lord's Supper as a sign that can be understood in various ways. Firstly, the Lord's Supper, as signified by the bread and 
wine, can be understood as 'an evident sign of spiritual recollection' (Moltmann 1977:252). As a remembrance feast, Christ is present by his Spirit who 'recalls him to us, and the bread and wine are merely the outwards signs of our spiritual communion with Christ' (Moltmann 1977:252). Zwingli interpreted the Lord's Supper in this sense. However, Zwingli's 'Platonic concept of spirit hindered him from perceiving the presence of the crucified one in the Spirit of the resurrection' (Moltmann 1977:252). Secondly, the Lord's Supper can be understood as the earthly:

sign of the presence of the God who has become man and of the man who has been exalted to God. Then the bread and wine signify that which they are according to Christ's promise - the body and blood of Christ. (Moltmann 1977:252)

Moltmann (1977) alludes to Luther as interpreting the Lord's Supper within this framework. When we understand the presence of Christ in the Lord's Supper:

along the same lines as the incarnation, then the Christological difference between what happened on Golgotha and what happens on the altar can be easily overlooked; while if we understand it in the framework of his exaltation, then it is easy to ignore the eschatological difference between the supper in history and the feast in the kingdom of God. (p. 253)

Thirdly, the Lord's Supper can be understood as 'a token of the future' (Moltmann 1977:253). The bread and wine are symbols or 'fore-tokens' of the eschatological feast (Moltmann 1977:253). The groups who celebrate the Lord's Supper in this sense, understand the celebration to be a:

love feast for the celebration of life, fellowship, hope and work for peace and righteousness in the world. The remembrance on which this hope is based reaches back to Old Testament prophecy. (Moltmann 1977:253)

With this line of thought, Moltmann (1977:253) argues that interpreting the Lord's Supper in spatial concepts is indicative of a 'one-sided view'. Against the backdrop of the eschatological context of the Lord's Supper, 'the experience of time is itself transformed' - it is 'opened up once and for all, in order to be consummated in his parousia' (Moltmann 1977:254). The proclamation of the Word, the bread and wine, the fellowship and the spirit of the Lord's Supper, are embraced by the 'eschatological presence of Christ so that there is no need to localize it any further' (Moltmann 1977:254). Moltmann (1977) advocates a renewed way of sacramental thinking here:

not - Christ is present in the feast here or there, but - the feast is held in his presence and carries those who partake of it into the eschatological history of Christ, into the time between the cross and the kingdom which takes its quality from his presence. (p. 255)

He conclusively views the sacraments as the means of proclamation and not as the means of grace. The sacraments serve as the means of remembered hope and is a 'mark of the history of the Spirit' which does not confer grace as Schillebeeckx argues, but 'joins the past and the future, history and eschatology in a unique way, and becomes [present] the token of liberating grace' (Moltmann 1977:256-257).
Following from Moltmann's eschatological approach and the 20th century Protestant theological impulse to identify Christ or the Spirit as primal sacrament, led to the emphasis that Christ and the Spirit are both acting in and through the sacraments to 'bind believers to Christ' and to each other within the church (Moore-Keish Martha in Boersma \& Levering 2015:399). Forsythe (1917:177) posits that the sacraments are 'acts of Christ really present by his Holy Spirit in the church. It is Christ doing something through the Church as His body'. Sacraments, he adds further, are not mere keepsakes reminding us of Jesus who has departed:

they are real means by which the risen Christ is present, conveying love to believers here and now. Nor are they tokens for separate individuals; sacraments are inherently public, corporate acts of the church. (Moore-Keish Martha in Boersma \& Levering 2015:399)

Torrance (1975:82), whilst affirming Barth's understanding of Christ as the primal sacrament in whom the sacraments are grounded, emphasised further that the sacraments serve as the means of the believer's participation or koinonia 'in the mystery of Christ and his church through the koinonia or communion of the Holy Spirit'. In this way he was able to clarify the corporate nature of the sacraments as well as the 'resistance to any kind of sacramental minimalism' (MooreKeish Martha in Boersma \& Levering 2015:400).

Effectively then, Protestantism in the early 20th century encountered varied interpretations as to whether the sacraments were mere signs or symbols 'pointing beyond themselves to a reality elsewhere - a view often (perhaps unfairly) attributed to Zwingli' (Moore-Keish Martha in Boersma \& Levering 2015:400). The response to such variations has proposed 'fuller understandings of sign and symbol, challenging dualistic presumptions that divide sign from reality' (Moore-Keish Martha in Boersma \& Levering 2015:400). Many Protestant theologians have posited that sacraments as signs are 'modes of personal communication from God to humanity' (Moore-Keish Martha in Boersma \& Levering 2015:400). Forsythe (1917:176), for example, argues that the sacraments are 'Christ in a real presence giving anew his redemption'. He (Forsythe 1917:176) further viewed them as the means by which Christ in and through the Spirit acts in the church. Tillich (1963), however, argues that the:

sacraments are not signs but symbols. Signs point beyond themselves; symbols participate in the power of what they symbolize. In sacraments, the Spirit uses inherent qualities of symbols (water, bread, wine) to enter man's spirit. (p. 123; also see Moore-Keish Martha in Boersma \& Levering 2015:400)

Torrance (1975) likewise insist that:

sacramental theology has suffered from a rigid separation of sign and thing, stemming from Augustine's definition of sacrament, and that sacramental signs participate in the reality that they signify. Signs do not merely illustrate the thing signified, but establish and re-present it. (p. 95-99; also see Pannenberg 1998:292, 348ff.) 
Boersma (2011:111-112) posits a 'sacramental ontology in which symbol and reality are not separated, but symbols participate in the reality to which they point' (also see Moore-Keish Martha in Boersma \& Levering 2015:401). As sacramental symbol, other Protestant scholars have argued that in the sacraments and more specifically the Eucharist, believers encounter 'the presence of the absence of God', which gives us the awareness of the 'radical otherness of the risen Christ' (Farwell 2005:73-78; Moore-Keish Martha in Boersma \& Levering 2015:401; Pickstock 1998). Torrance (1975:82-84) cautions that too much concentration on the liturgical acts of the church 'could distract from the main meaning of sacrament, which is the mystery of Christ' (also see Moore-Keish Martha in Boersma \& Levering 2015:401).

Dulles' sacramental thinking affirms that the sacramental model of the church can 'lead to a sterile aestheticism and to an almost narcissistic self-contemplation' which is the case with Schillebeeckx's hermeneutics (Dulles 1987:195). To avoid this Dulles (1987:195) suggests, as a remedy to this development, the consideration of the 'values of structure, community, and mission brought out in the other models'. Because the Eucharist 'celebrates and solidifies the union of the faithful with one another' and signifies the 'already' aspect of the 'not yet' sacramental eschatological anticipation of the final, eternal form of the heavenly marriage celebration, he postulates that this is the only model that seems to have the exceptional capacities to incorporate the 'sound' features of the other four models and hints at the 'possibility of using this model as the basis for a systematic ecclesiology' (Dulles 1987:70, 206). According to Dulles (1987:193), Schillebeeckx is a speculative theologian in that he has fixed and rigid sacramental hermeneutical taste. Dulles (1987:193) intimates the exclusive sacramental approach as being 'humanly and spiritually disastrous' and calls for an open and broader theological dialogue among the varying theological entities. Dulles, undoubtedly in contrast to Schillebeeckx, maintains an inclusive approach in his ecclesiology, and seeks ways to find reasonable solutions to a holistic ecclesiology that embraces Protestant theological thought. Chauvet (1995:177-178), unlike Schillebeeckx, correctly posits that the church is not identical with Christ also see Hancock 2014:29). He (Chauvet 1995:177-178) argues that the 'presence of the absence of God' is the 'paradox of the God who is fully disclosed in the crucified, resurrected, and ascended Christ and yet whose absence is (re) narrated in the Church's sacramental celebration as presence' (also see Hancock 2014:29).

This article has attempted to show that Protestant Evangelicalism can only benefit from a contemporary cohesive exploration of sacramental ecclesiology whilst maintaining that the sacraments do not confer grace and are not the only proper modes of encounter with God. Although not exhaustive, it does open up avenues of critical thought of not letting sacramental ecclesiology triumph over the grace of God in Christ by his Spirit. The sacraments - as essential marks, signs and symbols of the church with dynamic pneumatological spiritual value signifying the thing signified (the atoning eschatological work of Christ) remains at the heart of Protestant Evangelicalism thought, but not in the Roman Catholic sense. Like the proclamation of the Word, the sacraments are the means of proclamation that attest to the past, present and future work of Christ within the eternal Trinitarian outworking dynamic. In spite of the tensions surrounding the 'real' and 'spiritual' presence of Christ in the sacraments, there is still a definitive and dynamic systemic awareness of the Word, sacraments and church that serve as the proclamatory means to an end (parousia).

\section{Reappropriation}

The remaining differences between the Roman Catholic as espoused by Schillebeeckx, Orthodox and Protestant positions, notwithstanding the in-house differences within each of these movements, is a clarion call for more contemporary work on this subject. Tillich (1948:112) came to the conclusion that 'the solution of the problem of nature and sacrament is today a task on which the very destiny of Protestantism depends'. It was vital, he argued, that 'if Protestantism is to come to its full realization' that a 'rediscovery of the sacramental sphere' take place (Tillich 1948:94). He (Tillich 1948:102-103) proposed that 'natural objects can become bearers of transcendent power and meaning ... by being brought into the context of the history of salvation'. Was he right? Both Tillich (conceptualising of God through symbols) and Schillebeeckx (encounter with God through the sacraments) argue for mediating symbols to encounter God. When one limits one's encounter with God to the sacraments or symbols, one does a disservice to the work the Holy Spirit. Contrary to what Scripture says in John 3:

The wind blows wherever it pleases. You hear its sound, but you cannot tell where it comes from or where it is going. So it is with everyone born of the Spirit, (v. 8)

Schillebeeckx persists with his traditional argument.

On the other hand, Reformation thought has developed its own complexities. Whilst Luther advocated a co-existence, containing or 'interpenetration' of Jesus' physical body and blood in the bread and wine, Calvin maintained a purely influential ('spiritual or dynamic') presence of Christ therein, that is, 'the bread and wine contain spiritually the body and blood' of Jesus (Erickson 2001:364-366). He defined the church in terms of the proclamation of the Word and the proper administration of the sacraments. Zwingli, however, advocated the Lord's Supper as a 'mere commemoration' of the death of Christ but not without value, that is, the believer receives 'by faith the benefits of Christ's death' (Erickson 2001:365). His interpretation undoubtedly found its basis in 1 Corinthians 11:26: 'For as often as you eat this bread and drink this cup, you proclaim the Lord's death until he comes' 
(Erickson 2001:366). The view of 'mere commemoration' is not universally held. Bruce Ware (2010:229-247), for example holds a more nuanced view of Zwingli's position. Ware alludes to the 'textured character of Zwingli's view' which has its 'relative richness when compared to popular reductionist [mis?] understandings of his position' as well as the 'striking similarities he shared with John Calvin's view of the Supper when compared to that of Martin Luther or of the Roman Catholic Church' (Ware 2010:229). Ware is suggesting that those holding to a reductionist view of his position have often misunderstood Zwingli.

Moltmann (1977:289-300) is right when he argues that the church, as God's eschatological or messianic community (instrument), is in 'the process of the Holy Spirit' and is best defined as the 'Church in the power of the Holy Spirit'. This is the essence of the instrumental reality of the grace of God in Christ in the church. Furthermore, when considering the sacraments, one must 'not see the Spirit in the sacraments, but the sacraments in the movement and the presence of the Spirit' (Moltmann 1977:289). This is a significant hermeneutic element that Schillebeeckx has neglected. Moltmann (1977:289) poignantly puts this matter to rest by categorically emphasising that "there is no "Spirit of the sacraments" and no "Spirit of the ministry," there are sacraments and ministries of the Spirit'.

Scampini posits that, although the contemporary dialogues on sacramentality have not yet resolved all the divergent issues, they have, however, laid the foundational springboard in resolving these divergences (Boersma \& Levering 2015): Firstly, there is an 'acknowledgement of the Christological roots of the sacraments'. Secondly, there is the 'recognition that the unique and unrepeatable event of Jesus Christ presents itself in his church through the Word proclaimed and the sacrament celebrated'. Thirdly, there is the 'increasing assumption within the Protestantism realm of the ecclesial dimension of worship and, consequently, of the value of sacramental rites for the life of the church' and fourthly:

our theological-doctrinal understanding has been enriched by a greater awareness of the anthropological and cultural foundations underlying the sacramental event, brought to the fore by contemporary research into symbolism, semiotics, and linguistics. (p. 687).

The sacraments are Christ's instruction that must be acted upon. Like the proclamation of the Word, they communicate the gift from God which undoubtedly seeks a response. Therefore, the effect of the sacraments in each recipient is 'always the result of a harmonic exchange between the gift of God and one's personal attitude' (Boersma \& Levering 2015:688). They bring to the fore the 'mystery of the Incarnation' through the Spirit which, by faith, is visibly expressed and celebrated by the worshipers in the church (Boersma \& Levering 2015:689). 'Symbolic memorialism' or remembrance and 'symbolic parallelism' (Elliott 2016:106111) make dynamic the rhythms of constant grace.
The Zwingli-Bullinger confluence finds much of its sacramental ecclesiological expression in the work of Moltmann (1977) who offers the solution of 'the sending of the Holy Spirit as the Sacrament of the Kingdom':

Granted the remaining difference in Protestant-Catholic convergence - Christ as the exclusive sacrament of God, or the church as the fundamental sacrament and Christ as the primal sacrament - could this not be overcome through the Trinitarian understanding of the eschatological gift of the Holy Spirit as the sacrament? (p. 202)

This solution has biblical and theological merit. This article posits further that Calvin's expressions (not necessarily what he meant by them) of 'spiritual depth' and 'spiritual participation' be reinterpreted and re-appropriated within the Zwingli-Bullinger confluence for a more nuanced renewed alternative, ecclesiology for Protestantism as a whole. Bullinger is moving beyond Zwingli to accommodate Calvin as best as he can. This is not so that he may present a Calvinistic view of the Lord's Supper, but that he may, independently of both Calvin and Zwingli, present a view that is uniquely Bullingerian. Van Dyke argues that Bullinger's 'affirmation of divine gracious activity in the Lord's Supper signals an important difference from Zwingli, who understood the congregation, in its acts of dedication and gratitude, to be the primary subjects in the sacrament' (Smith 2008:72). Van Dyke's expression of 'divine gracious activity' is better described as the 'rhythms of grace'.

Effectively, Bullinger builds on Zwingli's foundation of 'symbolic memorialism' with its subjective emphasis by 'accommodating' Calvin's objective emphasis in the Supper. Bullinger's 'symbolic parallelism' meant that the 'eating of sacramental elements does not in itself confer grace, but the eating of the sacramental elements "parallels" the analogous action. The bread and wine are a testimony to divine grace, not an instrument of divine grace' (Van Dyke in Smith 2008:73). Bullinger's 'symbolic parallelism' contrasts with the 'symbolic instrumentalism' (Elliott 2016:83-116) of Calvin. Whilst Zwingli was comfortable with the use of the term instrument to describe the Lord's Supper (albeit in a different way to Calvin), Bullinger, however, regarded the use of the term as misleading and avoided it (Stephens 2010:74). The Zwingli-Bullinger confluence has the potential to revise and retrieve a unified system of sacramentality within the Reformed and Free Church traditions. Zwingli and Bullinger, in contrast to Schillebeeckx, present views on sacramental theology that are consistent with Scripture. It is interesting that both Baptist and Pentecostal responses to the Reformed view, presented by Van Dyke, have been well received:

Hers [Van Dyke's] is the best brief explanation of the subject I have ever read. Most leave Zwingli completely out, as if he were not Reformed! I am delighted to know that at least Van Dyke considers it to be a part of the Reformed tradition. (Smith 2008:87)

\section{Acknowledgements}

This article is based on my doctoral dissertation published at the North-West University (Potchefstroom Campus, 
South Africa) in association with Greenwich School of Theology, United Kingdom entitled, 'The hermeneutics of sacrament in the theology of Edward Schillebeeckx: A theological inquiry of the church as sacrament' (Elliott 2016).

\section{Competing interests}

The author declares that he has no financial or personal relationships which may have inappropriately influenced him in writing this article.

\section{References}

Bebbington, D., 1989, Evangelicalism in modern Britain: A history from the 1730's to the 1980's, Unwin Hyman, London, UK.

Bloesch, D., 1973, The evangelical renaissance, Eerdmans, Grand Rapids, MI.

Boersma, H., 2011, Heavenly participation: The weaving of a sacramental tapestry Eerdmans, Grand Rapids, MI.

Boersma, H. \& Levering, M., 2015, The Oxford handbook of sacramental theology, Oxford University Press, Oxford, UK.

Bouyer, L., 2004, The Word, church and sacraments, Ignatius Press, San Francisco, CA.

Chauvet, L., 1995, Symbol and sacrament: A sacramental reinterpretation of Christian existence, transl. P. Madigan \& M. Beaumont, Liturgical Press, Collegeville, MN.

De Chirico, L., 2003, Evangelical theological perspectives on post-Vatican II Roman Catholicism, vol. 19, European Academic Publishers, Berlin, Germany.

Dulles, A., 1987, Models of the church, Doubleday, New York.

Elliott, D.D., 2016, The Hermeneutics of Sacrament in the Theology of Edward Schillebeeckx: A theological inquiry of the church as sacrament, $\mathrm{PhD}$ thesis, NorthWest University in association with Greenwich School of Theology UK, Potchefstroom, South Africa.

Erickson, M., 1997, The evangelical left: Encountering post-conservative evangelical theology, Baker Book House, Grand Rapids, MI.

Erickson, M., 2001, Introducing Christian doctrine, Baker Academic, Grand Rapids, MI. Farwell, J., 2005, This is the night: Suffering, salvation, and the liturgies of Holy Week, T\&T Clark, Edinburgh, UK.

Forsythe, P., 1917, The church and the sacraments, Independent Press, London, UK.

France, R., \& McGrath, A., 1993, Evangelical Anglicans. Their role and influence in the church today, SPCK, London, UK.

Grenz, S., 1993, Revisioning evangelical theology: A fresh agenda for the 21st century, InterVarsity Press, Downers Grove, IL.
Grenz, S., 1994, Theology for the people of God, Broadman \& Holman, Nashville, TN.

Hancock, B., 2014, The scandal of sacramentality: The Eucharist in literary and theological perspective, James Clarke \& Company, Cambridge, UK.

Hodge, C., 1952, Systematic theology, vol. 3, Eerdmans, Grand Rapids, MI.

Lee, A.S., 2011, 'From sacrament of salvation to sign that interrupts: The evolution in Edward Schillebeeckx's theology of the relationship between the church and the world', PhD thesis, University of Notre Dame, Notre Dame, viewed 12 August 2015, from http://etd.nd.edu/ETD-db/theses/available/etd-0725201173401/ unrestricted/LeeAS072011D.pdf

McGrath, A., 1994, Evangelicalism and the future of Christianity, Hodder \& Stoughton, London, UK.

Mannion, G., \& Van der Borght, E., 2011, John Calvin's ecclesiology: Ecumenical perspectives, Bloomsbury, T\&T Clark, London.

Marsden, G., 1984, Evangelicalism and modern America, Eerdmans, Grand Rapids, MI.

Moltmann, J., 1977, The church in the power of the Spirit, Harper \& Row, New York.

Noll, M., \& McDermott, G., 2010, What is an evangelical? The Oxford handbook of evangelical theology, Oxford University Press, New York, NY.

Olson, R., 1998, 'Does evangelical theology have a future?' viewed 21 February 2015, from http://www.christianitytoday.com/ct/1998/february9/8t2040.html

Pannenberg, W., 1998, Systematic theology, vol. 3, transl. G. Bromiley, Eerdmans, Grand Rapids, MI.

Pickstock, C., 1998, After writing: On the liturgical consummation of philosophy, Blackwell Publishers, Oxford, UK.

Schillebeeckx, E., 1963, Christ the sacrament of the encounter with God, Rowman \& Littlefield, New York.

Smith, G. (ed.), 2008, The Lord's supper: Five views, IVP Academic, Downer's Grove, IL.

Stephens, P., 2010, 'The sacraments in the confessions of 1536, 1549, and 1566: Bullinger's understanding in the light of Zwingli's', viewed 1 February 2016 from http://www.zwingliana.ch/index.php/zwa/article/download/93/4

Strong, A., 1907, Systematic theology, Revell, Westwood, NJ.

Tidball, D., 1994, Who are the evangelicals? Tracing the roots of today's movement, Marshall Pickering, London, UK.

Tillich, P., 1948, The Protestant era, University of Chicago Press, Chicago, IL.

Tillich, P., 1963, Systematic theology, vol. 3, University of Chicago Press, Chicago, IL.

Torrance, T., 1975, Theology in reconciliation, Chapman, London, UK.

Ware, B., 2010, 'The meaning of the Lord's Supper in the theology of Ulrich Zwingli (1484-1531)', in T. Schreiner \& M. Crawford (eds.), The Lord's Supper, pp. 229247, B\&H Publishing Group, Nashville, TN.

Wells, D., 1987, 'No offense: I am an evangelical: A search for self-definition', in A. Rudin \& M. Wilson (eds.), A Time to Speak. The Evangelical-Jewish Encounter, p. 22, Eerdmans, Grand Rapids, MI.

White, J., 1983, Sacraments as God's self-giving, Abingdon Press, Nashville, TN 